\title{
CELLULASE AND XYLANASE ACTIVITY DURING THE DECOMPOSITION OF THREE AQUATIC MACROPHYTES IN A TROPICAL OXBOW LAGOON
}

\author{
Sciessere, L. ${ }^{1}$; Cunha-Santino, M. B. ${ }^{2}$; Bianchini Jr., I. ${ }^{1,2}$ \\ ${ }^{1}$ Universidade Federal de São Carlos, Programa de Pós-Graduação em Ecologia e Recursos Naturais, São Carlos, SP, Brasil; \\ ${ }^{2}$ Universidade Federal de São Carlos, Departamento de Hidrobiologia, São Carlos, SP, Brasil.
}

Submitted: September 20, 2010; Approved: January 31, 2011.

\begin{abstract}
Due to the connection between enzymatic activity and degradation of different fractions of organic matter, enzyme assays can be used to estimate degradation rates of particulate and dissolved organic carbon in freshwater systems. The aim of this study was to quantify and model the enzymatic degradation involving the decomposition of macrophytes, describing temporal activity of cellulases (EC 3.2.1.4 and EC 3.2.1.91) and xylanase (EC 3.2.1.8) during in situ decomposition of three aquatic macrophytes (Salvinia sp., Eichhornia azurea and Cyperus giganteus) on the surface and water-sediment interface (w-s interface) of an oxbow lagoon (Óleo lagoon) within a natural Brazilian Savanna Reserve. Overall, the enzymatic degradation of aquatic macrophytes in Óleo lagoon occurred during the whole year and was initiated together with leaching. Xylanase production was $c a$. 5 times higher than cellulase values due to easy access to this compound by cellulolytic microorganisms. Enzymatic production and detritus mass decay were similar on the surface and w-s interface. Salvinia sp. was the most recalcitrant detritus, with low mass decay and enzymatic activity. E. azurea and C. giganteus decomposition rates and enzymatic production were high and similar. Due to the physicochemical homogeneity observed in the Óleo lagoon, the differences between the decay rates of each species are mostly related with detritus chemical quality.
\end{abstract}

Key words: enzymes, litterbags, mass decay, particulate organic matter.

\section{INTRODUCTION}

Aquatic macrophytes play an important role in the detritus food chain and metabolism of aquatic systems (12). These detritus can be responsible for $c a .50 \%$ of the organic matter and nutrient inputs in these systems (43). After senescence, the bulk of macrophyte tissue enters the detritus pool, where microorganisms are involved in its breakdown and mineralization (16). The structural compounds (cellulose, hemicelluloses and lignin) represent up to $70 \%$ of the aquatic macrophytes dry weight and the remaining mass is represented by the protoplasmatic fraction and hydrosolubles compounds (7).

Bacteria and fungi, with their respective extracellular

\footnotetext{
*Corresponding Author. Mailing address: Universidade Federal de São Carlos, Programa de Pós-Graduação em Ecologia e Recursos Naturais, São Carlos, SP, Brasil.; E-mail: irineu@ufscar.br
} 
enzyme capabilities, act together in the decomposition and mineralization of plant material in aquatic ecosystems (31), which is an important step in the nutrient and carbon cycle. These microorganisms need to produce extracellular enzymes to break structural compounds into smaller molecules that can be assimilated (8). Abiotic factors such as $\mathrm{pH}(20)$, temperature (24) and nutrients (19) influence the decomposition rates together with detritus chemical quality (30). The rates of microbial degradation of lignocellulosic detritus influence both the secondary production and rates of nutrient regeneration in aquatic ecosystems (2).

Cellulose is the major component of lignocellulosic detritus and its complete hydrolysis needs a multicomponent enzyme system comprised of three major enzymes (endoglucanase, exoglucanase and $\beta$-glucosidase) (3). In aerobic conditions, the microorganisms secrete a combination of those enzymes into the environment, which acts in synergy on the substrate, known as noncomplexes systems (39). The second major group of cellulolytic systems is the complexed systems wherein the cellulases are organized in relation to each other so that their action can be collective. They are typically produced by anaerobic organisms (22)

Hemicelluloses are the second most common polysaccharides in nature and represent about 20-35\% of lignocellulosic biomass (32). In contrast to cellulose, hemicelluloses are easily hydrolysable polymers and do not form aggregates (27). Xylan is the most abundant of the hemicelluloses (14) and its hydrolysis requires a range of xylanases and accessory enzymes (11).

The most important enzymes related to particulate organic carbon decomposition are those involved in the degradation of lignocellulosic materials (35). There is a general consensus that studying extracellular enzymes involved in decomposition may provide valuable information about the nutrient and carbon cycle in ecosystems (30). There are few in situ studies in enzymatic decomposition of tropical aquatic ecosystems (30, 26) and deficient knowledge of enzymatic decomposition in multispecies cultures and mixed communities (22).

Due to the connection between enzyme activity and degradation of different fractions of organic matter, enzyme assays can be used to estimate degradation rates of particulate and dissolved organic carbon in freshwater systems (36). The aim of this study is to quantify and model enzymatic degradation involving the decomposition of macrophytes, describing temporal cellulase and xylanase activity during decomposition of three aquatic macrophytes (Salvinia sp. Aubl., Eichhornia azurea Kunth and Cyperus giganteus Vahl) on the surface and water-sediment interface of an oxbow lagoon.

\section{MATERIAL AND METHODS}

The Ecological Station of Jataí (21 $33^{\circ}$ to $21^{\circ} 37^{\prime} \mathrm{S}$ and $47^{\circ} 45^{\prime}$ to $47^{\circ} 51^{\prime} \mathrm{W}$ ) has 13 oxbow lagoons of the Mogi-Guaçu river in a Brazilian Savanna Reserve of Luiz Antonio, SP. The Óleo lagoon, located at $400 \mathrm{~m}$ from the river, is shallow and small $\left(\mathrm{Z}_{\text {máx }}=5.5 \mathrm{~m}\right.$ and $\left.17.800 \mathrm{~m}^{2}\right)$, and has dissolved oxygen values varying from 0.01 to $7.70 \mathrm{mg} \mathrm{L}^{-1}$ on the surface and from 0.88 to $2.91 \mathrm{mg} \mathrm{L}^{-1}$ on the w-s interface and is an acid lagoon ( $\mathrm{pH}$ from 4.01 to 6.79) (28). The macrophyte community is well developed in the littoral zone, comprising 13 species (28) of floating, emergent and submersed life forms.

\section{Physicochemical parameters}

The physicochemical parameter data were collected every sampling day $(1,3,5,30,60,100,120,150,200,250$ and 300 days) in the Óleo lagoon. The $\mathrm{pH}$ values, electrical conductivity, water temperature and dissolved oxygen were measured in the lagoon with a multi-parameter checker (Horiba - U-10). Water samples were collected and taken to the laboratory to analyze the dissolved organic carbon (TOC analyzer - Shimadzu 5000A), total nitrogen (40) and total phosphorus (38). 


\section{Litter bag incubation}

The plants were collected in the Óleo lagoon, washed in tap water and dried $\left(45^{\circ} \mathrm{C}\right)$ at a constant weight in the laboratory. The 216 litter bags $(20 \times 20 \mathrm{~cm}$; mesh size $=0.4$ $\mathrm{mm}$ ) were prepared with $15 \mathrm{~g}$ (DW) of Salvinia sp., Eichhornia azurea and Cyperus giganteus fragments previously dried (72 for each species). The litter bags were incubated in the sites where the respective species is most abundant in the lagoon in two incubation depths (surface $\mathrm{Z} \approx 0.2 \mathrm{~m}$ and water-sediment interface $\mathrm{Z} \approx 3.0 \mathrm{~m}$ ) on January 2008. Every sampling day, 6 litter bags (3 from surface and 3 from water-sediment interfaces) were taken to the laboratory to analyze the remaining particulate material.

In order to quantify the remaining organic matter content, the remaining detritus dried at $40-50{ }^{\circ} \mathrm{C}$ until the constant dry weight was weighed (mass loss analysis) and incinerated in a muffle furnace at $550{ }^{\circ} \mathrm{C}$ for two hours. The cellulose and hemicellulose contents in the detritus were measured using gravimetric methods according to Crampton \& Maynard (9) and Han \& Rowell (13).

\section{Enzymes activities}

For each sampling day, 3 sub-samples (2.0 g FW) were used for enzymes assays. The sub-samples were blended (Ultra-Turrax model T10; Germany) with $10 \mathrm{~mL}$ of acetate buffer (50 mM /pH 5.2), sonicated (ultrasound Unique, Brazil) and centrifuged $\left(3,000 \mathrm{x}\right.$ g, $30 \mathrm{~min}, 4^{\circ} \mathrm{C}$; Heraeus 122 Instruments, Megafuge 3.0R, Germany). These enzymatic extracts were used in the cellulase and xylanase activity determination, both determined by spectrophotometric methods (Amersham Biosciences, Ultrospec 2100 pro, Sweden). The cellulase (EC 3.2.1.4 and EC 3.2.1.91) and xylanase (EC 3.2.1.8) activities were determined using the method described by Mandels et al. (23), and Highley (15), respectively. The reducing sugars released by the enzyme action on a specific substrate (pure cellulose filter (Whatman $\mathrm{n}^{\circ} 1$ for cellulase and xylan for xylanase)) were quantified using the Somogy method
(540 nn) (37).

\section{Mathematical modeling of organic matter decay}

The temporal variation of remaining particulate organic matter (POM) (ash free) was fitted to a biphasic decay model (21) using non-linear regression, the iterative algorithm of Levenberg-Marquardt (29) according to equation 1 :

$$
P O M=\left(P O M_{L S} \times e^{-k_{T^{t}}}\right)+\left(P O M_{R} \times e^{k_{R} t}\right)
$$

where: $\mathrm{POM}_{\mathrm{LS}}=$ initial labile organic matter content $(\%)$; $\mathrm{POM}_{\mathrm{R}}=$ Initial particulate refractory organic matter content $(\%) ; \mathrm{k}_{\mathrm{T}}=\mathrm{k}_{1}+\mathrm{k}_{2} ;$ global mass loss coefficient (= labile mineralization coefficient $\left(\mathrm{k}_{1}\right)+$ soluble leachate coefficient $\left(\mathrm{k}_{2}\right)\left(\right.$ day $\left.\left.^{-1}\right)\right) ; \mathrm{k}_{\mathrm{R}}=$ refractory mass loss coefficient $\left(\right.$ day $\left.^{-1}\right)$.

The half-time $\left(\mathrm{t}_{1 / 2}\right)$ of organic matter decay was calculated by Equation 2 (7):

$$
t_{\frac{1}{2}}=\ln (0.5) /-k
$$

\section{Mathematical modeling of cumulative enzyme production over time}

The temporal variations of cumulative cellulase and xylanase activities were fitted to an exponential curve using non-linear regression (iterative algorithm of LevenbergMarquardt) following Press et al. (29). The coefficient of enzymatic activity $\left(\mathrm{k}_{\mathrm{p}}\right)$ values were derived from the sigmoid fittings. In the procedures, the time evolution of enzyme production was described by Equation 3:

$$
E=E \max \left(1-e^{-k} p^{2}\right)
$$

where: $\mathrm{E}=$ accumulated produced enzyme $\left(\mu \mathrm{mol} \mathrm{min}{ }^{-1}\right.$ $\left.\mathrm{ml}^{-1} \mathrm{~g}^{-1}\right) ; \mathrm{E}_{\max }=$ maximum enzyme produced $\left(\mu \mathrm{mol} \mathrm{min} \mathrm{m}^{-1} \mathrm{ml}^{-1}\right.$ $\left.\mathrm{g}^{-1}\right) ; \mathrm{k}_{\mathrm{P}}=$ enzyme production coefficient $\left(\right.$ day $\left.^{-1}\right) ; \mathrm{t}=$ time (day). 
The doubling-time $\left(\mathrm{D}_{1 / 2}\right)$ of maximum enzyme production was calculated according to Equation 2; in this case used as $\mathrm{k}_{\mathrm{P}}$.

\section{Statistical analysis}

All statistical analyses were conducted using a non-parametric variance test (Kruskall-Wallis), values were considered significant at $\mathrm{p} \leq 0.05$ and performed by PAST®.

\section{RESULTS}

\section{Physicochemical parameters}

The physicochemical parameters (Table 1) did not show significant differences between the three incubation sites, only between surface and w-s interface. The $\mathrm{pH}$ values varied around 5.0 during the experiment. Electrical conductivity varied from $0.006 \mathrm{mS} . \mathrm{cm}^{-1}$ to $0.008 \mathrm{mS} . \mathrm{cm}^{-1}$ on the surface and from $0.014 \mathrm{mS} . \mathrm{cm}^{-1}$ to $0.079 \mathrm{mS} . \mathrm{cm}^{-1}$ on the w-s interface. The water temperature in Óleo lagoon varied from $17.4{ }^{\circ} \mathrm{C}$ to 27.8 ${ }^{\circ} \mathrm{C}$. Values of dissolved oxygen (DO) on the surface varied from $0.8 \mathrm{mg} . \mathrm{L}^{-1}$ to $7.7 \mathrm{mg} . \mathrm{L}^{-1}$ and from $0.04 \mathrm{mg} . \mathrm{L}^{-1}$ to 2.91 mg. $\mathrm{L}^{-1}$ on the w-s interface. Dissolved organic carbon was higher in the E. azurea incubation site $\left(6.2 \mathrm{mg} . \mathrm{L}^{-1}\right.$ surface and $7.6 \mathrm{mg} . \mathrm{L}^{-1} \mathrm{w}-\mathrm{s}$ interface) than on the Salvinia sp. (3.6 mg.L 1/3.2 mg. $\left.\mathrm{L}^{-1}\right)$ and C. giganteus $\left(3.2 \mathrm{mg} . \mathrm{L}^{-1} / 2.7 \mathrm{mg} . \mathrm{L}^{-1}\right)$. Nutrient values were similar in the lagoon incubation sites and depths. Total nitrogen varied from $0.6 \mathrm{mg} . \mathrm{L}^{-1}$ to $0.9 \mathrm{mg} . \mathrm{L}^{-1}$ and total phosphorus was $0.03 \mathrm{mg} . \mathrm{L}^{-1}$ on the surface and w-s interface.

Table 1. Physicochemical parameters of Óleo lagoon

\begin{tabular}{|c|c|c|c|c|c|c|c|c|c|}
\hline & pH & $\begin{array}{c}\text { EC } \\
\text { mS.cm }^{-1} \\
\end{array}$ & $\begin{array}{c}\mathbf{T}_{\max } \\
{ }^{\mathbf{0}} \mathbf{C} \\
\end{array}$ & $\begin{array}{c}\mathbf{T}_{\min } \\
{ }^{\mathbf{0}} \mathbf{C} \\
\end{array}$ & $\begin{array}{l}\text { DO }_{\text {max }} \\
\text { mg. }^{-1}\end{array}$ & $\begin{array}{l}\text { DO }_{\min } \\
\text { mg.L }^{-1}\end{array}$ & $\begin{array}{c}\text { DOC } \\
\text { mg.L }^{-1}\end{array}$ & $\begin{array}{c}\mathrm{Nt} \\
\text { mg.L }^{-1}\end{array}$ & $\begin{array}{c}\text { Pt } \\
\text { mg.L }{ }^{-1} \\
\end{array}$ \\
\hline \multirow[b]{2}{*}{$\mathrm{P} 1$} & \multicolumn{9}{|c|}{ surface } \\
\hline & 5.3 & 0.008 & 25.6 & 17.4 & 5.45 & 0.8 & 3.6 & 0.6 & 0.02 \\
\hline \multirow{3}{*}{$\begin{array}{l}\text { P2 } \\
\text { P3 }\end{array}$} & 5.1 & 0.006 & 26.6 & 18.8 & 6.67 & 1.43 & 6.2 & 0.6 & 0.03 \\
\hline & 5.3 & 0.006 & 27.8 & 18.6 & 7.7 & 0.87 & 3.2 & 0.6 & 0.03 \\
\hline & \multicolumn{9}{|c|}{ W-s interface } \\
\hline P1 & 5.4 & 0.014 & 24.7 & 17.6 & 1.22 & 0.04 & 3.2 & 0.7 & 0.03 \\
\hline P2 & 5.6 & 0.079 & 24.5 & 17.4 & 1.89 & 0.05 & 7.6 & 0.9 & 0.03 \\
\hline P3 & 5.4 & 0.059 & 24.9 & 17.6 & 2.91 & 0.12 & 2.7 & 0.7 & 0.03 \\
\hline
\end{tabular}

oxygen, $\mathrm{DOmin}=$ minimum dissolved oxygen, $\mathrm{DOC}=$ dissolved organic carbon, $\mathrm{Nt}=$ total nitrogen, $\mathrm{Pt}=$ total phosphorus.

\section{Detritus decay}

Temporal mass loss (Figure 1) follows the bimodal pattern. The initial phase was represented by a fast decay of labile particulate organic matter $\left(\mathrm{POM}_{\mathrm{LS}}\right), 11 \%$ (E.azurea) to $43 \%$ (Salvinia sp.) (Table 2). The detritus of Salvinia sp. had a mass decay which was significantly different $(\mathrm{p} \leq 0.05)$ from the two other species. These detritus presented the highest percentage of $\mathrm{POM}_{\mathrm{LS}}(41 \%$ surface and $43 \% \mathrm{w}-\mathrm{s}$ interface), however, the decay rates $\left(\mathrm{k}_{\mathrm{t}}\right)$ were the lowest $\left(0.22\right.$ day $^{-1}$ surface and w-s interface) and, consequently, the higher half- times (3.15 days surface and w-s interface). E. azurea $\mathrm{POM}_{\mathrm{LS}}$ percentage was the lowest between the three species $(11 \%$ surface and $15 \% \mathrm{w}-\mathrm{s}$ interface) and the highest $\mathrm{k}_{\mathrm{T}}$ values (1.27 day $^{-1}$ surface and 0.70 day $^{-1} \mathrm{w}-\mathrm{s}$ interface), together with the lowest half-time (0.55 day surface and 0.99 day w-s interface). C. giganteus was the only species to present differences between surface and $\mathrm{w}-\mathrm{s}$ interface $\mathrm{POM}_{\mathrm{LS}}$ percentage $(15 \%$ surface and $26 \% \mathrm{w}-\mathrm{s}$ interface). The decay rates were intermediate; 0.57 day $^{-1}$ surface with a half-time of 1.22 days and a 0.33 day $^{-1} \mathrm{w}-\mathrm{s}$ interface, with a half-time of 2.10 days. 

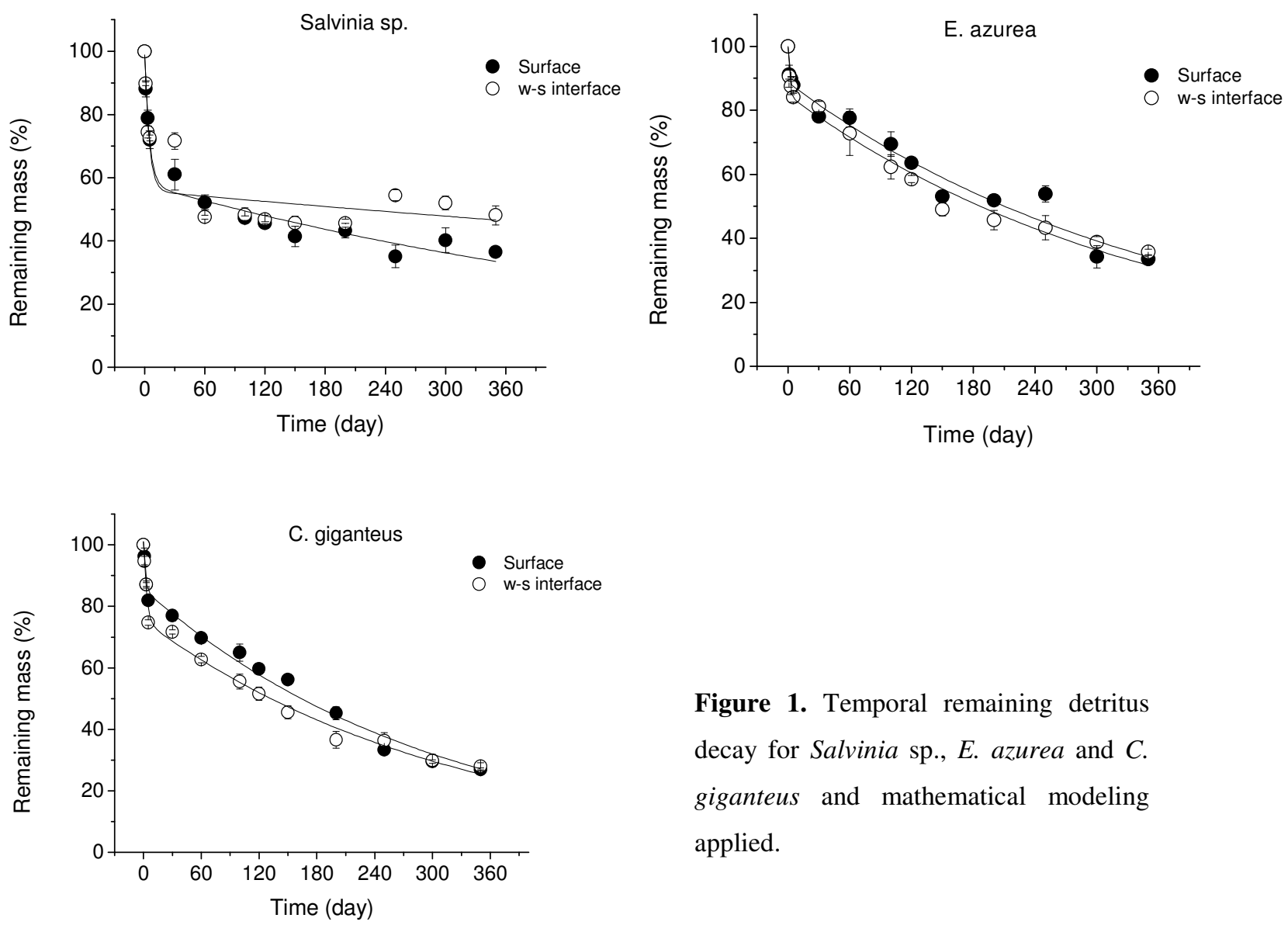

Figure 1. Temporal remaining detritus decay for Salvinia sp., E. azurea and $C$. giganteus and mathematical modeling applied.

The period of $\mathrm{POM}_{\mathrm{LS}}$ decay was followed by the degradation azurea and $C$. giganteus $\mathrm{POM}_{\mathrm{R}}$ presented similar decay patterns of recalcitrant organic matter $\left(\mathrm{POM}_{R}\right)$. The percentages of $\mathrm{POM}_{R}$ in Salvinia sp. detritus was $58 \%$ and $56 \%$ respectively for the surface and w-s interface and were the lowest values between the three species. The decay rate in the surface $\left(0.001\right.$ day $\left.^{-1}\right)$ was twice the w-s interface value (0.0005 day $\left.{ }^{-1}\right)$, consequently, Salvinia sp. and did not show differences between the surface and w-s interface. The percentage of $\mathrm{POM}_{\mathrm{R}}$ was $89 \%$ (surface) and $85 \%$ (w-s interface) in E. azurea samples and $86 \%$ (surface) and $75 \%$ (w-s interface) in C. giganteus. The decay rates were 0.002 days $^{-1}$ to E. azurea and 0.003 days $^{-1}$ to C. giganteus (surface and $\mathrm{w}-\mathrm{s}$ $\mathrm{POM}_{R}$ half-time was twice as fast on the surface (Table 2). E. interface). Half-time values were 346 and 231 days, respectively.

Table 2. Parameters obtained from organic matter decay model.

\begin{tabular}{|c|c|c|c|c|c|c|c|c|c|c|c|}
\hline & $\begin{array}{c}\text { POM }_{\text {LS }} \\
(\%)\end{array}$ & $\mathbf{E}$ & $\begin{array}{c}\text { kt } \\
\left(\mathrm{day}^{-1}\right)\end{array}$ & $\mathbf{E}$ & $\begin{array}{c}\mathbf{t}_{1 / 2} \\
(\text { day })\end{array}$ & $\begin{array}{c}\mathbf{P O M}_{\mathrm{R}} \\
(\%)\end{array}$ & $\mathbf{E}$ & $\begin{array}{c}\mathbf{k}_{\mathrm{R}} \\
\left(\mathrm{day}^{-1}\right)\end{array}$ & $\mathbf{E}$ & $\begin{array}{c}\mathbf{t}_{1 / 2} \\
(\text { day })\end{array}$ & $\mathbf{r}^{2}$ \\
\hline \multicolumn{12}{|c|}{ Surface } \\
\hline Salvinia sp. & 40.6 & 4.0 & 0.22 & 0.05 & 3.15 & 57.8 & 2.7 & 0.001 & 0.0002 & 693 & 0.97 \\
\hline E. azurea & 11.2 & 4.9 & 1.27 & 1.56 & 0.55 & 88.7 & 2.5 & 0.002 & 0.0002 & 346 & 0.96 \\
\hline C.giganteus & 15.3 & 3.4 & 0.57 & 0.32 & 1.22 & 85.7 & 2.2 & 0.003 & 0.0001 & 231 & 0.98 \\
\hline \multicolumn{12}{|c|}{ Sediment-water interface } \\
\hline Salvinia sp & 43.1 & 8.1 & 0.22 & 0.1 & 3.15 & 55.8 & 5.1 & 0.0005 & 0.0002 & 1386 & 0.83 \\
\hline E. azurea & 14.8 & 3.8 & 0.70 & 0.4 & 0.99 & 84.8 & 2.36 & 0.002 & 0.0002 & 346 & 0.97 \\
\hline C.giganteus & 25.7 & 3.3 & 0.33 & 0.0001 & 2.10 & 75.4 & 2.38 & 0.003 & 0.0002 & 231 & 0.98 \\
\hline
\end{tabular}

* where: POMLS= labile fraction of organic matter; $\mathrm{k}_{\mathrm{t}}=$ Global decay coefficient (labile fraction mineralization coefficient + leaching coefficient); POMR= refractory fraction of organic matter; $\mathrm{k}_{\mathrm{R}}=$ refractory fraction mineralization coefficient; $\mathrm{t} 1 / 2=$ half-time; $\mathrm{E}=$ error. 


\section{Enzymes activity}

Cellulase and xylanase activities were detected since the beginning of the decomposition process (Figure 2). The cellulase activity did not show significant differences between the three species $(\mathrm{p} \geq 0.05)$. Xylanase activity presented significant differences between Salvinia sp., E. azurea and $C$. giganteus $(\mathrm{p} \leq 0.05)$ and was five times higher than the cellulase production. Incubation depths did not influence the enzymatic production of cellulase or xylanase ( $p \geq 0.05)$. A peak of enzymatic production of $C$. giganteus during the first five days of experiment could be observed.

\section{Cellulase}
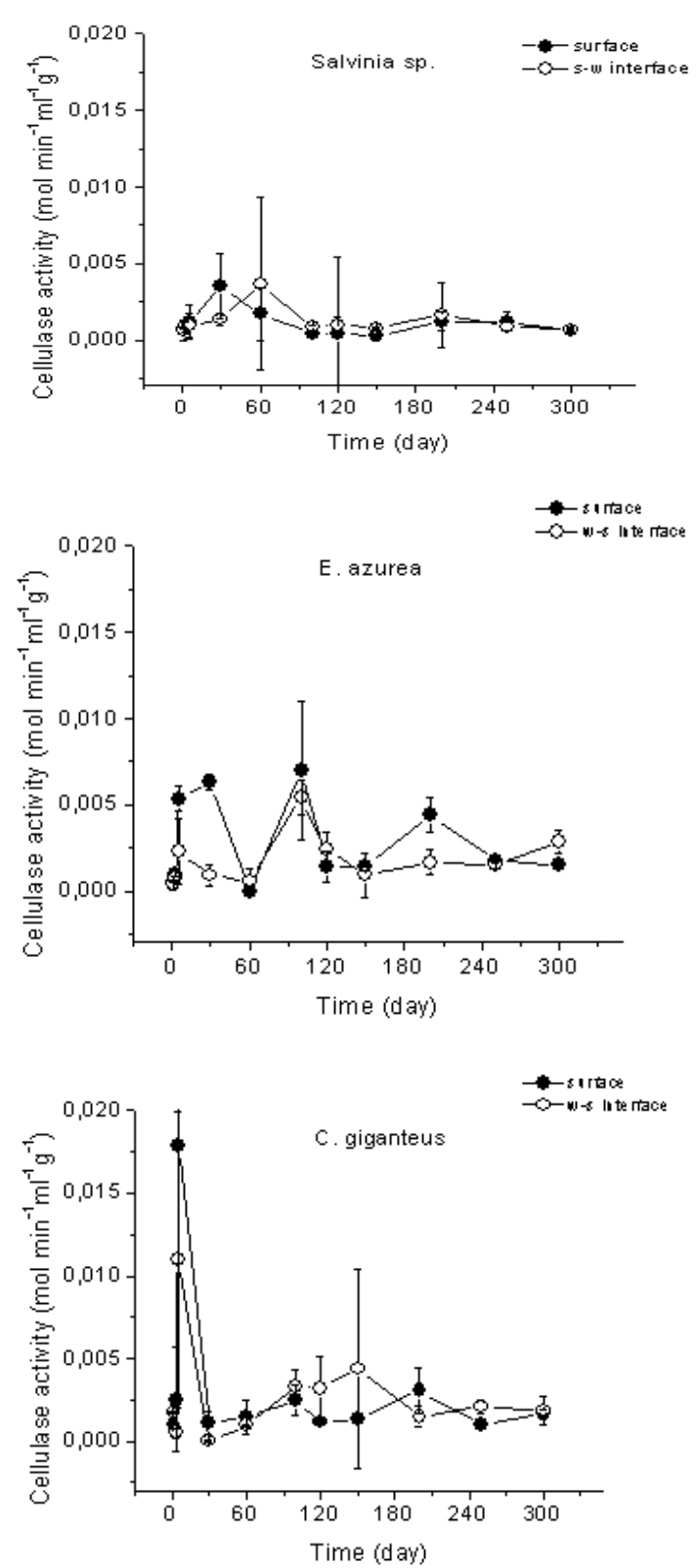

Xylanase
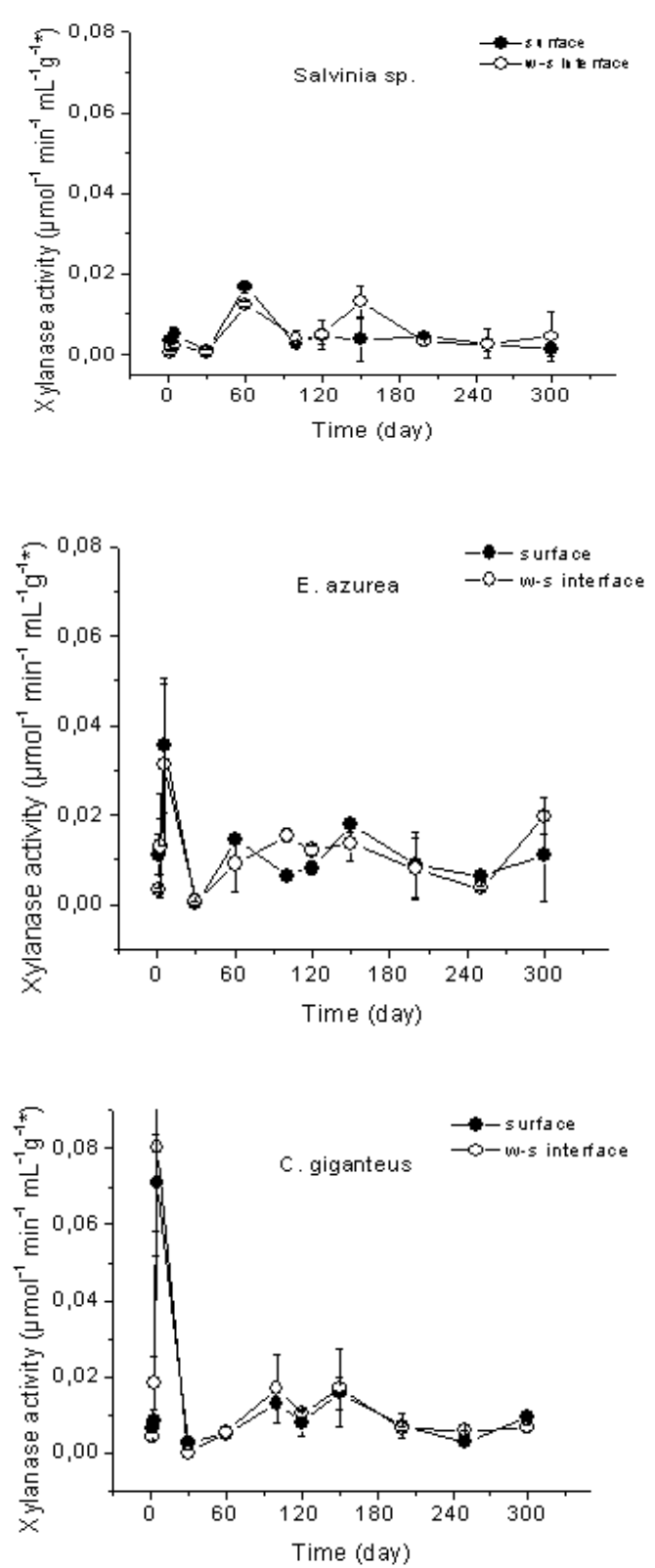

Figure 2. Temporal variation and standard deviation of cellulase and xylanase (surface and water-sediment interface) production during decomposition of Salvinia sp., E. azurea and C. giganteus. 
Salvinia sp. had the lowest values of enzymatic production (Table 3 ), maximum production $\left(\mathrm{E}_{\max }\right)$ of cellulase was $0.01 \mathrm{~mol}$ $\min ^{-1} \mathrm{~mL}^{-1} \mathrm{~g}^{-1}$ (surface and w-s interface) with a coefficient production $\left(\mathrm{k}_{\mathrm{p}}\right)$ of $0.02 \mathrm{day}^{-1}$ (surface) and $0.01 \mathrm{day}^{-1}$ (w-s interface), resulting in doubling times $\left(\mathrm{D}_{1 / 2}\right)$ of 35 and 69 days, respectively. The xylanase maximum production was $0.05 \mathrm{~mol}$ $\min ^{-1} \mathrm{~mL}^{-1} \mathrm{~g}^{-1}$ on the surface and $0.07 \mathrm{~mol} \min ^{-1} \mathrm{~mL}^{-1} \mathrm{~g}^{-1}$ on the w-s interface. The $\mathrm{k}_{\mathrm{p}}$ was 0.01 day $^{-1}$ and $\mathrm{D}_{1 / 2}$ of 69 days (surface) and $0.04 \mathrm{~mol} \mathrm{~min}^{-1} \mathrm{~mL}^{-1} \mathrm{~g}^{-1}$ and $\mathrm{D}_{1 / 2}$ of 17 days (w-s interface).

Detritus of E. azurea (Table 3) had a cellulase $\mathrm{E}_{\max }$ of 0.03 mol $\min ^{-1} \mathrm{~mL}^{-1} \mathrm{~g}^{-1}$ (surface) and $0.02 \mathrm{~mol} \min ^{-1} \mathrm{~mL}^{-1} \mathrm{~g}^{-1}$ (w-s interface). For this plant, $k_{d}$ in the surface $\left(0.01\right.$ day $\left.^{-1}\right)$ was twice the w-s interface value $\left(0.005\right.$ day $\left.^{-1}\right)$ with $D_{1 / 2}$ of 69 and 139 days, respectively. The xylanase maximum production was $0.12 \mathrm{~mol}$ $\min ^{-1} \mathrm{~mL}^{-1} \mathrm{~g}^{-1}$ (surface and $\mathrm{w}$-s interface) and, as cellulase, was faster on the surface $\left(0.02\right.$ day $\left.^{-1}\right)$ with a $D_{1 / 2}$ of 35 days. The w-s interface presented $\mathrm{kp}$ of 0.01 day $^{-1}$ and $\mathrm{D}_{1 / 2}$ of 69 days.

C. giganteus (Table 3) had the highest values of cellulase and xylanase production. The values of cellulase $\mathrm{E}_{\max }$ were $0.003 \mathrm{~mol}$ $\min ^{-1} \mathrm{~mL}^{-1} \mathrm{~g}^{-1}$ (surface and $\mathrm{w}-\mathrm{s}$ interface). The cellulase production coefficient was 14 times higher on the surface $\left(0.14\right.$ day $\left.^{-1}\right)$ with a $\mathrm{D}_{1 / 2}$ of 5 days than on the w-s interface $\left(0.01\right.$ day $\left.^{-1}\right)$ and $\mathrm{D}_{1 / 2}$ of 69 days. The xylanase maximum production was $0.12 \mathrm{~mol} \mathrm{~min}^{-1} \mathrm{~mL}^{-1}$

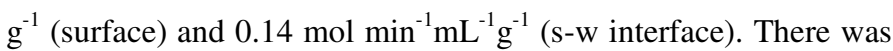
no difference between the surface and $\mathrm{s}-\mathrm{w}$ interface for $\mathrm{k}_{\mathrm{p}}(0.13$ day $\left.^{-1}\right)$ and $\mathrm{D}_{1 / 2}(5$ days $)$.

Table 3. Parameters obtained from kinetic model for accumulated cellulose and xylanase production.

\begin{tabular}{|c|c|c|c|c|c|c|}
\hline & $\begin{array}{c}\mathbf{E}_{\max } \\
\left(\mathrm{mol} \mathrm{min}^{-1} \mathrm{~mL}^{-1} \mathrm{~g}^{-1}\right)\end{array}$ & $\mathbf{E}$ & $\begin{array}{c}\mathbf{k}_{\mathbf{p}} \\
\left(\text { day }^{-1}\right)\end{array}$ & $\mathbf{E}$ & $\begin{array}{c}D_{1 / 2} \\
(\text { day })\end{array}$ & $\mathbf{r}^{2}$ \\
\hline \multicolumn{7}{|c|}{ Cellulase } \\
\hline \multirow[t]{2}{*}{ Salvinia sp. } & 0.01 & 0.0005 & 0.02 & 0.006 & 35 & 0.93 \\
\hline & 0.01 & 0.0000007 & 0.01 & 0.001 & 69 & 0.97 \\
\hline \multirow[t]{2}{*}{ E. azurea } & 0.03 & 0.002 & 0.01 & 0.002 & 69 & 0,95 \\
\hline & 0.02 & 0.002 & 0.005 & 0.001 & 139 & 0.96 \\
\hline \multirow{2}{*}{ C. giganteus } & 0.03 & 0.001 & 0.14 & 0.050 & 5 & 0.86 \\
\hline & 0.03 & 0.003 & 0.01 & 0.004 & 69 & 0.84 \\
\hline \multicolumn{7}{|c|}{ Xilanase } \\
\hline \multirow[t]{2}{*}{ Salvinia sp. } & 0.05 & 0.0029 & 0.01 & 0.002 & 69 & 0.96 \\
\hline & 0.07 & 0.0102 & 0.04 & 0.001 & 17 & 0.97 \\
\hline \multirow[t]{2}{*}{ E. azurea } & 0.12 & 0.01 & 0.02 & 0.060 & 35 & 0.80 \\
\hline & 0.12 & 0.014 & 0.01 & 0.003 & 69 & 0.87 \\
\hline \multirow[t]{2}{*}{ C. giganteus } & 0.12 & 0.007 & 0.13 & 0.050 & 5 & 0.83 \\
\hline & 0.14 & 0.009 & 0.13 & 0.050 & 5 & 0.83 \\
\hline
\end{tabular}

*where: $\mathrm{E}_{\max }=$ maximum enzyme production, $\mathrm{E}=$ error, $\mathrm{k}_{\mathrm{P}}=$ enzyme production coefficient and $\mathrm{D}^{1} / 2=$ doubling-time.

\section{Cellulose and Hemicellulose content}

The lowest initial contents of cellulose (32\%) were observed in Salvinia sp. and in C. giganteus, the highest content (57\%) (Table 4). It was not possible to detect decay in the cellulose content of Salvinia sp., E. azurea had a loss of about $10 \%$ and $C$. giganteus a loss of about $20 \%$ (Table 4 ). The hemicellulose content (Table 4) was similar between the 3 species $(\approx 30 \%)$ and a loss of this content was not observed.
Table 4. Cellulose and hemicellulose initial and final content (\%) of Salvinia sp., E. azurea and C. giganteus.

\begin{tabular}{|c|c|c|}
\hline & Cellulose $(\%)$ & Hemicellulose (\%) \\
\hline & \multicolumn{2}{|c|}{ initial } \\
\hline Salvinia sp. & 32 & 26 \\
\hline E. azurea & 43 & 33 \\
\hline C. giganteus & 57 & 26 \\
\hline & \multicolumn{2}{|c|}{ final } \\
\hline Salvinia sp. surface & 31 & 36 \\
\hline w-s interface & 32 & 36 \\
\hline E. azurea surface & 32 & 33 \\
\hline w-s interface & 34 & 21 \\
\hline C. giganteus surface & 38 & 36 \\
\hline $\mathrm{w}-\mathrm{s}$ interface & 36 & 32 \\
\hline
\end{tabular}




\section{DISCUSSION}

In general, there were no physicochemical variations between the three incubation sites. The variations observed between the surface and w-s interface were, mainly, dissolved oxygen and electrical conductivity. Even with the low depth of Óleo lagoon $\left(\mathrm{Z}_{\max } 3.5 \mathrm{~m}\right)$, the $\mathrm{DO}$ values on the w-s interface were lower than $1.0 \mathrm{mg} . \mathrm{L}^{-1}$ most of the year, showing anaerobic processes. The electrical conductivity (EC) values were nearly seven times higher on the w-s interface than on the surface. The release of ions from the sediment increases these $\mathrm{EC}$ values on the w-s interface.

Leaching is a physical process, which occurs during the first 7 days after the macrophyte senescence (10). During this period, Salvinia sp. detritus had the higher values of decay coefficient and half-time (0.22 day ${ }^{-1}$ and 3.15 days), compared with E. azurea and $C$. giganteus. Since the physical parameters show no significant differences between the incubation sites, the slow decay of Salvinia sp. is related with this plant chemical composition. E. azurea and C. giganteus $\mathrm{POM}_{\mathrm{L}}$ decay was faster on the surface $\left(1.27\right.$ day $^{-1}$ and 0.57 day $^{-}$ $\left.{ }^{1}\right)$ than on the w-s interface $\left(0.70\right.$ day $^{-1}$ and 0.33 day $\left.^{-1}\right)$ and this could be related with the lower temperature at the w-s interface samples which were decomposed.

Parallel to leaching, an enzymatic activity peak was observed in the first days of E. azurea and C. giganteus decomposition (Fig. 2). This could be related with the release of nutrients during the leaching process. Many authors have suggested that most nutrient elements in aquatic macrophytes are rapidly leached in the initial period of litter decomposition (34): labile compounds like sugars, amino-acids, aliphatic acids (42) and nutrients such as dissolved nitrogen (e.g. ammonia), ortho-phosphate and total phosphorus (43). These released nutrients can increase the bacterial production (33), causing the enzymatic production peak. Nunes et al. (25) also observed an initial peak in cellulase and xylanase production in an in vitro anaerobic experiment with 3 other macrophytes of Óleo lagoon
(Ricciocarpus natans (L.) Corda, Oxycaryum cubense (Poepp. \& Kunth) and Cabomba furcata Schult. \& Schult).

Litter quality as defined by chemical composition markedly influences the decomposition rates of different types of plant litter (34), mainly the $\mathrm{POM}_{\mathrm{R}}$ degradation. Salvinia sp. was the more recalcitrant species, with the highest half-time values for $\mathrm{POM}_{\mathrm{R}}$ (693 and 1386 days). The recalcitrance of Salvinia generous was also observed in previous study; in a decomposition experiment with macrophytes of an Italian wetland, Salvinia natans had the lowest decay rates (18). Barik et al., observed low decay rates for Salvinia cullata $(0.28 \%$ day $^{-1}$ ) compared to Eichhornia crassipes $\left(1.49 \%\right.$ day $^{-1}$ ) samples (6).

There was a direct relation between the mass loss and enzymatic activity shown by higher detritus mass loss and higher $\mathrm{k}_{\mathrm{R}}$ values in samples with great enzymatic activity $(E$. azurea and $C$. giganteus). Fiber disposition is a dominant structural feature limiting the rate and extent of using biomass materials (22) and can be the cause of different enzymatic productions between the three species. The higher enzymatic degradation activity on E. azurea and $C$. giganteus detritus caused a greater $\mathrm{POM}_{\mathrm{R}}$ loss $\left(\mathrm{t}_{1 / 2}\right.$ values were twice the Salvinia sp. values in the surface and 4 times the w-s interface values Table 2).

Cellulose and hemicelluloses are connected in the plant structure and decomposition. There is an inter-relationship between the systems that regulate these compounds (39). Cellulose fibers are embedded in a matrix of, primarily, hemicelluloses (22), filling the voids around cellulose fibrils and providing coupling to lignin (5). This disposition facilitates microorganism degradation. Thus, the higher xylanase activity observed in detritus of Salvinia sp., E. azurea and C. giganteus (nearly, 5 times higher (Table 3)) could occur due to the easy access of the microorganisms in this component in relation to cellulose. Furthermore, hemicelluloses must be degraded, at least partially, before cellulose (17).

The results observed for cellulose and hemicelluloses 
contents seem to contradict the detritus mass decay and enzymatic activity, since it was not possible to observe decay in hemicelluloses contents, even with a great xylanase activity. The microorganisms involved in cellulose degradation produce multiple enzymes to degrade plant cell materials, known as enzyme systems (39) and can co-produce enzymes active specifically on hemicelluloses (22). Therefore, a greater decay in hemicelluloses contents was expected.

The general low enzyme activity observed during the experiment could be related not only to the detritus quality but with the system characteristics, such as low nutrient levels (Table 1). In permanent tropical aquatic systems, where temperature and moisture are not constraining, nutrient availability and decomposer activity determines the decomposition rates together with chemical properties of the decomposing material (4). Low decomposition rates are common in plants inhabiting poor nutrient sites, characterized by high nutrient absorption (1). Nutrient inputs can increase decomposition rates (30). The slight increase in enzymatic activity during the dry season (Fig. 2) can be related to the macrophyte senescence and nutrients release by the leaching of those detritus. Thus, in addition to constraints imposed by the structure of fiber itself, limitations imposed by diffusion and transport of the cellulolytic agent to the site of the enzymatic attack, may severely limit the use of fibers in some habitats (44).

Even with the occurrence of anoxia periods on the w-s interface (28) and possible release of nutrients, the proximity of the two incubation depths (less than $3.0 \mathrm{~m}$ ) could influence the results of statistical analysis, that did not show differences between the surface and w-s interface in detritus mass decay and enzymatic production, even with an increase in xylanase maximum production on the w-s interface in E. azurea and $C$. giganteus detritus.

Overall, the enzymatic degradation of aquatic macrophytes in Óleo lagoon occurs during all seasons and initiates together with leaching. After senescence, the aquatic macrophytes can be decomposed in the floating detritus bulk or on the w-s interface. Enzymatic production and detritus mass decay are similar in these two sites. Due to the environmental homogeneity in this lagoon, it can be inferred that the chemical composition of the macrophytes detritus dominate the influence on decomposition rates (mass loss and enzymatic production) of aquatic macrophytes in this system. Xylanase production was higher due to the easier access to this compound by cellulolytic microorganisms.

\section{REFERENCES}

1. Aerts, E.; Chapin, F.S. (2000). The mineral nutrition of wild plants revisited: A re-evaluation of processes and patterns. Adv. Ecol. Res. 30, $1-67$.

2. Ágoston-Szabó, E.; Dinka, M.; Némedi, L.; Horváth, G. (2006). Decomposition of Phragmites australis rhizome in a shallow lake. Aquat. Bot. 85, 309-316.

3. Ahmed, Z.; Banu, H.; Rahman, M.M.; Akhter, F.; Haque, M.S. (2001). Microbial activity on the degradation of lignocellulosic polysaccharides. J. Biol. Sci., 1(10), 993-997.

4. Allison, S.D.; Vitousek, P.M. (2004). Extracellular Enzyme Activities and Carbon Chemistry as Drivers of Tropical Plant Litter Decomposition. Biotropica. 36 (3), 285-296.

5. Atalla, R.H.; Hackney, J.M.; Uhlin, I.; Thompson, N.S. (1993). Hemicelluloses as structure regulators in the aggregation of native cellulose. Int. J. Biol. Macromol. 15, 109-112.

6. Barik, S.K.; Mishra, S.; Ayyappan, S. (2000). Decomposition patterns of unprocessed and processed lignocellulosics in a freshwater fish pond. Aquat. Ecol. 34, 185-204.

7. Bianchini Jr., I. (2003). Modelos de crescimento e decomposição de macrófitas aquáticas. In: Thomaz, S.M.; Bini, L.B. (eds). Ecologia e manejo de macrófitas aquáticas. EDUEM, Maringá, Brazil, p. 85-126.

8. Chróst, R.J. (1991). Environmental Control of the synthesis and activity of aquatic microbial ectoenzymes. In: Chróst, R.J. (ed.) Microbial Enzymes in Aquatic Environments, Springer-Verlag, New York, USA, 29-60.

9. Crampton, E.W.; Maynard, L.A. (1938). The relation of cellulose and lignin content and nutritive value of animals feeds. J. Nutr. 15, 383-395.

10. Cunha-Santino, M.B.; Bianchini Jr., I. (2008). Carbon cycling potential from Utricularia breviscapa decomposition in a tropical oxbow lake (São Paulo, Brazil). Ecol. Model. 218, 375-385.

11. Cunha-Santino, M.B.; Sciessere, L.; Bianchini Jr., I. (2008). As 
atividades das enzimas na decomposição da matéria orgânica particulada em ambientes aquáticos continentais. Oecol. Bras. 12 (1), 30-41.

12. Gessner, M.O. (2000). Breakdown and nutrient dynamics of submerged Phragmites shoots in the littoral zone of a temperate hardwater lake. Aquat. Bot. 66 9-20.

13. Han, J.S.; Rowell, J.S. (1996). Chemical composition of fibres. Paper and composites from agro based resources. CEC Press, Boca Raton.

14. Heck, J.X.; Hertz, P.F.; Ayub, M.A.Z. (2002). Cellulase and xylanase production by isolated amazon Bacillus strains using soybean industrial residue based solid-state cultivation. Braz. J. Microbiol. 33, 213-218.

15. Highley, T.L. (1997) Carbohydrates assays. In: Dashek, W. V. (Ed.). Methods in plant biochemistry and molecular biology. CRC Press, Boca Raton, p. 309-321.

16. Kuehn, K.A.; Suberkropp, K. (1998). Decomposition of standing litter of the freshwater emergent macrophyte Juncus effuses. Freshwat. Biol. 40, 717-727.

17. Leschine, S.B. (1995). Cellulose degradation in anaerobic environments. Annu. Rev. Microbiol. 49, 399-426.

18. Longhi, D.; Bartoli, M.; Viaroli, P. (2008). Decomposition of four macrophytes in wetland sediments: Organic matter and nutrient decay and associated benthic processes. Aquat. Bot. 89, 303-310.

19. López, N.I.; Duarte, C.M.; Vallespinós; Romero, J.; Alcoverro, T. (1998). The effect of nutrient additions on bacterial activity in seagrass (Posidonia oceanica) sediments. J. Exp. Mar. Biol. Ecol. 224, 155-166.

20. López-Arquilla, A.I.; Marin, I.; Amils, B.R. (2001). Microbial Community Composition and Ecology of an Acidic Aquatic Environment: The Tinto River, Spain. Microb. Ecol. 41, 20-35.

21. Lousier, J.D; Parkinson, D. (1976). Litter decomposition in a cool temperature deciduous forest. Can. J. Bot. 54, 419-436.

22. Lynd, L.R.; Weimer, P.J.; van Zyl, W.H.; Pretorius, I.S. (2002). Microbial Cellulose Utilization: Fundamentals and Biotechnology. Microbiol. Mol. Biol. R. 66 (3), 506-577.

23. Mandels, M.; Andreotti, R.; Roche, C. (1976). Measurement of saccharifuing cellulose. Biotechnology and Bioengineering Symposium, 6, 21-33.

24. Mendelssohn, I.A.; Sorrell, B.K.; Brix, H.; Schierup, H.; Lorenzen, B.; Maltby, E. (1999). Controls on soil cellulose decomposition along a salinity gradient in a Phragmites australis wetland in Denmark. Aquat. Bot. 64, 381-398.

25. Nunes, M.F.; Cunha-Santino, M.B.; Bianchini Jr., I. Xylanase and cellulase activities during anaerobic decomposition on three aquatic macrophytes. Braz. J. Microbiol. (in press).

26. Penton, C.R.; Newman, S. (2007). Enzyme activity responses to nutrient loading in subtropical wetlands. Biogeochemistry. 84, 83-98.

27. Pérez, J.; Muñoz-Dorado, J.; Rubia, T.; Martinez, J. (2002). Biodegradation and biological treatments of cellulose, hemicellulose and lignin: an overview. Int. Microbiol. 5, 53-63.

28. Petracco, P. (2006). Efeito das variáveis abióticas na produção primária de Egeria najas e Utricularia breviscapa da lagoa do Óleo (Estação Ecológica de Jataí, Luiz Antônio, SP). São Carlos, Brasil, 110p. (Ph.D. Thesis. Programa de Pós-Graduação em Ecologia e Recursos Naturais, UFSCar).

29. Press, W.H.; Teukolsky, S.A.; Vetterling, W.T.; Flannery, B.P. (1993). Numerical Recipes in $C$ : the art of scientific computing. Cambridge University Press, New York.

30. Rejmánjová, E.; Sirová, S. (2007). Wetland macrophyte decomposition under different nutrient conditions: Relationships between decomposition rate, enzyme activities and microbial biomass. Soil Biol. Biochem. $39,526-538$.

31. Romaní, A.M.; Fischer, H.; Mille-Lindblom, C.; Tranvik, L.J. (2006). Interactions of bacteria and fungi on decomposing litter: differential extracellular enzyme activities. Ecology. 87 (10), 2559-2569.

32. Saha, B. C. Hemicellulose bioconversion. (2003) J .Ind . Microbiol. Biotechnol. 30, 279-291.

33. Sala, M.M.; Karner, M.; Arin, L.; Marrasé, C. (2001). Measurement of ectoenzyme activities as an indication of inorganic nutrient imbalance in microbial communities. Aquat. Microb. Ecol. 23, 310-311.

34. Shin, J.; Keum-Chul, Y.; Myung-Hun, Y.; Jae-Kuk, S. (2007). Decomposition and Nutrient Dynamics of Aquatic Macrophytes in Lake Paldang. J. Ecol. Field Biol. 30 (3), 231-236.

35. Sinsabaugh, R.L.; Antibus, R.K.; Linkins, A.E. (1991). An enzymatic approach to the analysis of microbial activity during plant litter decomposition. Agric. Ecosyst. Environ. 34, 43-54.

36. Sinsabaugh, R.L.; Moorhead, D.L. (1994). Resource allocation to extracellular enzyme production: A model for nitrogen and phosphorus control of litter decomposition. Soil Biol. Biochem. 26 (10), 1305-1311.

37. Somogyi, M. (1952). Notes on sugar determination. J. Biol. Chem. 195, 19-23.

38. Strickland, J.; Parsons, T. (1960). A manual of sea water analysis. Bull. Fish. Res. Bel. Can. 125, 1-185.

39. Tomme, P.; Warren, R.A.J.; Gilkes, N.R. (1995). Cellulose hydrolysis by bacteria and fungi. Adv. Microb. Physiol. 37, 1-81.

40. Vogel, A.I. (1992). Análise inorgânica quantitativa. Guanabara Dois S.A., Rio de Janeiro.

41. Warren, R.A.J. (1996). Microbial hydrolysis of polysaccharides. Аnпи. Rev. Microbiol. 50, 183-212.

42. Webster, J.R.; Benfield, E.F. (1986). Vascular plant breakdown in freshwaters ecosystems. Ann. Rev. Ecol. Syst. 17, 567-594.

43. Wetzel, R.G. (2001). Limnology: Lake and rivers Ecosystems. Academic Press, San Diego, CA.

44. Wilson, D.B. (2009). Evidence for a novel mechanism of microbial cellulose degradation. Cellulose. 16, 723-727. 